\title{
Bribery in the Private Sector as a Criminal Offence: Recent Developments in the European Union and their Impact on National Legislations - With a Focus on Greek Criminal Law
}

\author{
Elisavet Symeonidou-Kastanidou ${ }^{\star}$
}

\begin{abstract}
Bribery in the private sector has been defined as a crime in the last 15 years both in international and European texts, as well as in national legislations in which the act did not constitute a crime in the past. However, this formalisation has been criticised because of its vagueness and inability to locate a specific and socially significant entity to protect. This study attempts to identify the protected legal interest affected by the act and - in this context - to suggest concrete legislative interventions in the criminal law provisions that are crucial for the principles of legality and proportionality.
\end{abstract}

\section{Introduction: The phenomenon of bribery in the private sector}

The phenomenon of corruption in the development of business activity covers a wide range of behaviours. Primarily, it covers illicit payments to government officials so that companies acquire benefits that are related to state activity, such as licensing, granting other necessary documents for their establishment, or signing contracts for the procurement of public works. This type of private-to-public bribery, however, represents just a small segment of the corruption risks faced by companies in their business activity. ${ }^{1}$

From their establishment and trade with other companies to the expansion of their activities in other countries, enterprises have proven to provide a very fruitful ground for the development of acts of corruption, which take on different forms each time. Starting with the initial stages of forming a company, bribery usually takes the form of influencing those entrusted with the responsibility of staff selection, ${ }^{2}$ construction of infrastructure or supply of equipment, while there are more incidents of bribing bank officials to grant the necessary loans for establishing the business, as well as later to maintain its operation or expand its activities. According

\footnotetext{
${ }^{\star}$ Professor of Criminal Law, Aristotle University of Thessaloniki.

${ }^{1}$ For this type of bribery, the term "private - to - public bribery" is commonly used, as opposed to bribery coming from individuals and directed to individuals, for which the terms "private - to - private bribery" or simply "commercial bribery" are used. See D. Hess, Corruption in the value chain: private-to-private and private-to public corruption, in: Transparency International, Global Corruption Report 2009 - Corruption and the Private Sector, 2009, p. 19.

${ }^{2}$ For example, there have been reports on cases of bribing employees for hiring staff in US casinos (Associated Press, 21. 6. 2008), as well as nurses in Bahrain (Trade Arabia, 8. 10. 2008).
} 
to research conducted in 1999, more than one third of entrepreneurs surveyed consider bribing bank officials to ensure the approval of loans a serious problem for the development of their business activity. ${ }^{3}$

Acts of bribery also take place in the course of running a business. Managers who control procurement of company supplies or transactions with subcontractors are often likely to receive gifts in order to choose specific suppliers or other businessmen, who do not meet the specifications set down by their employer or who wish to gain an advantage over their competitors. ${ }^{4}$ Even when such transactions are assigned through invitations to tender and submissions of sealed bids, practices of corruption still exist, as interested parties bribe employees to obtain confidential information to strengthen their own bid or even offer information about their competitors' bids. Finally, bribery is also common in business sales or rendering of services. At this level, a company's own sales managers, such as the Honda car dealers - whose acts are often mentioned in recent years - may be tempted to take money by their counterparts in procurement departments in order to make sales targets and win lucrative business.

When a company expands its activities in more countries, the risk of a rise in corruption at all levels increases considerably. Companies without local market knowledge or business contacts often have to hire local agents or to establish joint ventures with local companies. These local agents often resort to acts of bribery to quickly achieve the goals for which they were hired. As a result, multinational companies engage in the "export of corruption". 6 In this framework, the globalisation of economy has led gradually to the globalisation of corruption in the private sector. This has been enhanced both by organised crime because of the significant amounts of money in its possession to reinforce its position in the legal economy, ${ }^{7}$ and by the gradual shrinking of the public sector for the benefit of the private one. In this way, acts of corruption that previously belonged to the private-to-public bribery now appear as private-to-private transactions.

Based on this, corruption in businesses today is considered as a significant problem that can seriously affect their operation. It is already noted in the introduction of the 2009 Global Corruption Report by Transparency International, which was dedicated to corruption in the private sector, that corruption in the business sector constitutes a particularly widespread phenomenon in modern

\footnotetext{
${ }^{3}$ See T. Beck/A. Demirgüç-Kunt/R. Levine, Bank Supervision and Corruption in Lending, Working Paper no. 11498 (Cambridge, MA: National Bureau of Economic Research, 2005).

${ }^{4}$ International Herald Tribune, 5. 11. 2008. See also "Der Spiegel" 10. 7. 1995, p. 22 et seq., about what became known as the "Opel scandal".

${ }^{5}$ See D. Bruce Johnsen, The Ethics of "Commercial Bribery": Integrative Social Contract Theory Meets Transaction Cost Economics, Journal of Business Ethics 2009, p. 797.

${ }^{6}$ For a more detailed analysis, see $D$. Hess, Corruption in the value chain: private-to-private and private-to public corruption, in: Transparency International, Global Corruption Report 2009 - Corruption and the Private Sector, 2009 , p. 20 / 21. Also see examples of private sector bribery in K. Chatzikostas, Bribery in the private sector, 2010, p. 38 et seq. [in Greek].

${ }^{7}$ See. G. Panousis, Corruption - Intertwining interests and political machine [in Greek], Poiniki Dikaiosyni 2006, p. 1022 .
} 
times, the importance of which was underestimated for many years. ${ }^{8}$ Of course, it is not easy to have statistical evidence on the precise extent of the phenomenon, because both bribery of state employees and bribery in the private sector belong to the so-called "hidden criminality", 9 not only because these forms of bribery cannot be easily revealed, but also because corporations are often reluctant to pursue actions publicly against commercial bribery because of the potentially negative impact on their reputation. Instead, corporations try to address the situation internally. ${ }^{10}$ Still, a survey conducted by Transparency International in 2008 among 2,700 senior business executives showed that one in four respondents identified corruption as the first major problem for their business, even more important than bureaucracy. ${ }^{11}$

\section{International and European texts defining bribery in the private sector}

Despite the widespread occurrence of corruption in the private sector, it was only in the last 15 years that the fight against it acquired international interest. In particular, efforts to deal with corruption legally in the framework of criminal law have been combined with the opening of markets at the beginning of the 90s, as well as the subsequent interest of the business world to ensure equal opportunities at international level. As a direct consequence of this interest, the OECD Convention to combat bribery of foreign public officials in international business transactions was signed in 1997 and came into force in 1999. The driving force behind the signing of this convention was the USA, which wanted in this way to balance the competitive disadvantages faced by American businesses as a result of the Foreign Corrupt Practices Act, which was passed in 1977, in response to the Lockheed scandal, and prohibited these companies to use methods of corruption in their dealings abroad. ${ }^{12}$ This Convention only refers, of course, to the obligation to criminalise acts of private -to- public bribery.

However, the international community's attitude towards corruption in the private sector changed significantly thereafter. The Council of Europe Criminal Law Convention on Corruption, signed in 1999, makes an explicit reference to the need to address not only bribery of public officials, but also of individuals working in private sector entities when the transaction takes place in the course of business activity. ${ }^{13}$ Articles 7 and 8 of the Convention specifically stipulate that states must

\footnotetext{
${ }^{8}$ See Transparency International, Global Corruption Report 2009 - Corruption and the Private Sector, 2009, p. xxvi.

${ }^{9}$ See $A$. Koller, Die Bekämpfung der Korruption in der Schweiz, ZStrR 1998, p. 126 et seq.

${ }^{10}$ A. Argandoña, Private-to-private Corruption, Journal of Business Ethics, 2003, p. 253 et seq.

${ }^{11}$ See D. Hess, Corruption in the value chain: private-to-private and private-to public corruption, in: Transparency International, Global Corruption Report 2009 - Corruption and the Private Sector, 2009, p. 23.

${ }^{12}$ See K. Abbott, Rule-making in the WTO: Lessons from the case of Bribery and Corruption, Journal of International Economic Law 2001, p. 275 et seq., B. Schünemann, Das Strafrecht im Zeichen der Globalisierung, GA 2003 , p. 308 et seq.

${ }^{13}$ Criminal Law Convention on Corruption, no. 173, Strasbourg, 27.I.1999
} 
adopt all legislative and other necessary measures to establish as a criminal offence, when committed intentionally in course of business activity, active and passive bribery of persons working in any capacity for private sector entities in order to act or refrain from acting in breach of their duties. ${ }^{14}$

A similar provision is also found in the United Nations Convention against Corruption, which came into force in December 2003. Under Article 21 of this Convention, each member state must assess whether to adopt such legislative or other measures to establish as criminal offences the active and passive bribery of persons working in any capacity for private sector entities so that they act or refrain from acting in breach of their duties in the course of economic, financial or commercial activities. ${ }^{15}$

Of course, the criminalisation envisaged by the aforementioned international texts is not binding. The United Nations Convention merely encourages states to consider whether to establish bribery in the private sector as a criminal offence, ${ }^{16}$ while the Council of Europe Convention recognises that states may reserve their right not to establish as a criminal offence under their domestic law, in part or in whole, the active and passive bribery in the private sector. ${ }^{17}$ Greece - as well as most member states - has ratified the Convention without these reservations.

Similar initiatives have been taken in the European Union as well, where two successive texts were published to address the phenomenon: first, the Council's Joint Action on corruption in the private sector on 22.12. $1998^{18}$ and thereafter the Framework Decision 2003/568/JHA. ${ }^{19}$ In these texts, the criminalisation of active and passive bribery in the private sector - the content of which is defined in a manner similar to that adopted by the Council of Europe and the United Nations -

\footnotetext{
${ }^{14}$ Article 7 - Active bribery in the private sector: "Each Party shall adopt such legislative and other measures as may be necessary to establish as criminal offences under its domestic law, when committed intentionally in the course of business activity, the promising, offering or giving, directly or indirectly, of any undue advantage to any persons who direct or work for, in any capacity, private sector entities, for themselves or for anyone else, for them to act, or refrain from acting, in breach of their duties". Article 8 - Passive bribery in the private sector: "Each Party shall adopt such legislative and other measures as may be necessary to establish as criminal offences under its domestic law, when committed intentionally, in the course of business activity, the request or receipt, directly or indirectly, by any persons who direct or work for, in any capacity, private sector entities, of any undue advantage or the promise thereof for themselves or for anyone else, or the acceptance of an offer or a promise of such an advantage, to act or refrain from acting in breach of their duties".

${ }^{15}$ Article 21 - Bribery in the private sector: "Each State Party shall consider adopting such legislative and other measures as may be necessary to establish as criminal offences, when committed intentionally in the course of economic, financial or commercial activities: (a) The promise, offering or giving, directly or indirectly, of an undue advantage to any person who directs or works, in any capacity, for a private sector entity, for the person himself or herself or for another person, in order that he or she, in breach of his or her duties, act or refrain from acting. (b) The solicitation or acceptance, directly or indirectly, of an undue advantage by any person who directs or works, in any capacity, for a private sector entity, for the person himself or herself or for another person, in order that he or she, in breach of his or her duties, act or refrain from acting".

${ }^{16}$ See also the Legislative Guide for the Implementation of the United Nations Convention against Corruption, $\mathrm{p}$. 99.

${ }^{17}$ Article 37 par. 1 of the Council of Europe Convention, no. 173 (1999).

${ }^{18}$ OJ L 358 of 31. 12. 1998, p. 2 - 4. For this Joint Action see A.Dionysopoulou, Thoughts on active and passive bribery in the private sector (Article 5, Law 3560/2007) [in Greek], Poinika Chronika 2009, p. 968, Ch. Mylonopoulos, The dogmatic foundations of criminal law in the new millennium, [in Greek] in: Hellenic Criminal Bar Association, Criminal law in the new international environment, p. 52.

${ }^{19}$ OJ L 192 of 31. 7. 2003 , p. $54-56$.
} 
becomes mandatory for member states. ${ }^{20}$ Therefore, the inclusion of this offence in national legislation constituted an obligation for most EU member states towards both the Council of Europe and the European Union.

\section{Greek legislation on bribery in the private sector}

Greek legislators formalised bribery in the private sector in the fifth article of Law 3560/2007, while a few months later, Law 3666/2008 established a more serious form of this crime, when the profits obtained through bribery exceed 73,000 Euros, threatening with up to ten years imprisonment for this specific action.

According to the relevant provision, bribery in the private sector is punishable when a person, in the course of business activity, promises or offers any undue advantage to any persons who direct or work in any capacity for a private sector entity, so as to achieve that they will act or refrain from acting in breach of their duties. The penalty for this active bribery is imprisonment from one to five years. The same sentence is imposed on employees in private sector entities, who in the course of business activity also require or receive the above benefits for carrying out or refraining from acts in violation of their duties. ${ }^{21}$

From the wording of this provision it can be concluded that Greek legislators, copying the choices made at international level, wanted to formalise only the acts of the so-called "aggressive" corruption in the private sector, that is, acts of bribery which attempt to ensure actions violating the employee's duties. ${ }^{22}$ Conversely, acts of bribery in performing legal duties are not considered criminal acts; however

\footnotetext{
${ }^{20}$ More specifically, in the Joint Action 98/742/JHA, while the act of bribery in the private sector is defined in a broad manner, similar to that in international conventions (Art. 2 and 3 par. 1), that Member States should "at least" establish as a criminal offence acts that lead to or could lead to distortion of competition in the common market and which result, or might result, in financial damage to others by the improper award or improper execution of a contract (Art. 2 and 3 par. 2). Instead, the Framework Decision 2003/568/JHA stipulates that States must take the necessary steps to establish as criminal offences all acts of active and passive bribery, when they are carried out in the course of business activities. A limitation of criminality is conceivable only when a Member State declares that it will only criminalize such conduct which involves, or could involve, a distortion of competition in relation to the purchase of goods or commercial services (Art. 2 par. 3).

${ }^{21}$ Specifically, the article states the following: "(1). A punishment of at least one year of imprisonment shall be imposed on anyone promising, offering or giving, directly or indirectly, intentionally in the course of business activity, any undue advantage or compensation to any person who directs or works in any capacity in a private sector entity, in exchange for acting or refraining to act in breach of their duties, as these are determined by the law, the contract of employment, the internal rules, orders or instructions of his/her superiors or as these result from the nature of their position in their employer's service... The same penalty shall be imposed on any director or employee in any capacity in a private sector entity, who intentionally in the course of business activity, demands or receives, directly or indirectly any undue advantages for himself/herself or for anyone else or accepts promise of such an advantage or consideration for acting or failing to act in breach of his/her duties. (2). The perpetrator of the acts referred to in paragraph 1 of this Article shall be punished with imprisonment of up to ten years if the value of the benefits or compensation exceeds the amount of seventy-three thousand $(73,000)$ Euros".

${ }^{22}$ For the different forms of corruption see I. Androulakis, Offences of corruption in the private sector [in Greek], in: N. Kourakis (ed.), Economic Crimes II, 2007, p. 333 et seq.
} 
these are punishable when committed in the context of operation in the public sector.

\section{The protected legal interest infringed by the crime of bribery in the private sector}

\section{Introductory remarks}

>International texts do not seem to offer a clear picture of the legal interests protected by the criminalisation of bribery in the private sector. "The reasons for introducing criminal law sanctions for corruption in the private sphere are manifold" according to the Explanatory Report to the Council of Europe Criminal Law Convention on Corruption. "First of all, because corruption in the private sphere undermines values like trust, confidence or loyalty, which are necessary for the maintenance and development of social and economic relations. Even in the absence of a specific pecuniary damage to the victim, private sector corruption causes damage to society as a whole". Secondly, the criminalisation of private sector corruption seems to be necessary in order to ensure respect for fair competition. Thirdly, it is also connected to the privatisation process. Over the years, important public functions have been privatised (education, health, transport, telecommunication etc). The transfer of such public functions to the private sector, often related to a massive privatisation process, entails transfers of substantial budgetary allocations and of regulatory powers. It is therefore logical to protect the public from the damaging effects of corruption in businesses as well, particularly since the financial or other powers concentrated in the private sector, which are necessary for their new functions, are of great social importance. $^{23}$

In the 2003 United Nations Convention, ambiguity as to the protected legal interest is even greater. The purpose of criminalisation, as noted in the Legislative Guide for the implementation of the United Nations Convention against Corruption, is to highlight the "importance of requiring integrity and honesty in economic, financial or commercial activities". 24

A similar ambiguity exists in European Union texts. "Member States attach particular importance to combating corruption in both the public and the private sector", states the Framework Decision 2003/568/JHA, "in the belief that in both those sectors it poses a threat to a law-abiding society as well as distorting competition in relation to the purchase of goods or commercial services and impeding on sound economic development". ${ }^{25}$ Even the subsequent Commission's Report to the European Parliament and the Council, on the evaluation of the way in which member states have transposed the provisions of the Framework Decision into their domestic legislation, notes in general terms that "corruption in the private

\footnotetext{
${ }^{23}$ See Explanatory Report to the Council of Europe Criminal Law Convention on Corruption, par. 52

${ }^{24}$ See Legislative Guide for the Implementation of the United Nations Convention against Corruption, n. 298.

${ }^{25}$ Framework Decision 2003/568/JHA, Preamble, par. 9.
} 
sector has a direct impact on competitiveness and economic development. By tackling private sector corruption, member states will reinforce the internal market and strengthen their economies. Furthermore, these measures will have a positive impact on relations with the European Community's external trade partners". 26

However, these broad statements do not actually seem to suggest a particular social interest, that has to be protected, the existence of which constitutes a prerequisite for the justification of any criminal sanction, but also for resolving interpretive problems with regard to the content of criminal law provisions. ${ }^{27}$ The privatisation process could, of course, justify the legislator's interest. Still, if criminalisation were linked only to the transfer of responsibilities from the public to the private sector, which is then called to exercise a part of state functions for the citizens, criminal sanctions would then have to be foreseen only for bribery within the "privatised" public sector ${ }^{28}$. However, as it is clear from both the texts of international conventions and the 2003 Framework Decision, the obligation to establish bribery as a crime concerns the entire private sector and not only companies to which the state has delegated some of its powers.

We must therefore look for a legal interest common to all acts of bribery in the private sector regardless of the type of services offered by individual private bodies and regardless of the nature of their business activity or their connection to the State. Various proposals have been put forward.

\section{The duty of loyalty}

Starting from the fact that the act for which gifts or other benefits are offered must be carried out by a person working in a private sector entity, in breach of the duties set by his / her employer, part of the theory has argued that the protected legal interest is primarily the duty of loyalty of the employee towards the employer. $^{29}$ Moreover, this is clearly stated as a protected value in the Report of the

\footnotetext{
${ }^{26}$ See Report from the Commission to the Council and the European Parliament under Article 9 of the Council Framework Decision 2003/568/JHA of 22 July 2003 on combating corruption in the private sector, 18. 6. 2007, p. 2, COM (2007) 328 final.

${ }^{27}$ For the protected legal interest as a fundamental concept of criminal law and a prerequisite of any criminalisation, see mainly the monographs by I. Manoledakis, The dialectical concept of protected legal interests, 1973 and The protected legal interest as a fundamental concept of criminal law, 1998 [in Greek]. See also the monographs by $N$. Dimitratos, Protected legal interest and teaching crime in criminal law, 1998, [in Greek], D. Spyrakos, The critical function of the concept of the protected legal interest, 1996, [in Greek], G. Sylikos, The materiality of protected legal interests in criminal law, 1995, as well as studies by G. Ktistakis, Criminal claim of the state between theory and practice, Poinika Chronika 1988, p. 173, [in Greek], D. Spinellis, The protected legal interest and its importance in modern teaching of Criminal Law, Poinika Chronika 1971, p. 721 et seq., p. 801 et seq. [in Greek].

${ }^{28}$ This is, for example, the case in Greece, where active and passive bribery in the "privatised" public sector has constituted a crime since 1972 (Art. 263A of the Criminal Code), while bribery in the whole private sector has only been criminalised since 2007 (Art. five of Law 3560/2007).

${ }^{29}$ See this view in I. Androulakis, Offences of corruption in the private sector, in: N. Kourakis (ed.), Economic Crimes II, 2007, p. 375, [in Greek], I. Androulakis, Die Globalisierung der Korruptionsbekämpfung, 2007, p. 332, 431, 475 et seq. See also K. Chatzikostas Bribery in the private sector, 2010, p. 21 and 60 et seq. [in Greek] and $A$. Dionysopoulou Thoughts on active and passive bribery in the private sector [in Greek], Poinika Chronika 2009, p. 970), who argue that the protected legal interest is the employee's loyalty towards his / her employer, though they strongly criticise this legislative choice.
} 
Scientific Council of the Hellenic Parliament on the draft bill which introduced the crime of bribery in the private sector into the Greek penal system, ${ }^{30}$ while the Explanatory Report on the Convention of the Council of Europe also states, as already mentioned, the need to criminalise acts of bribery that undermine the values of trust, confidentiality and loyalty.

This view is reinforced by the fact that the duties for the violation of which advantages are offered to the employee are defined in quite broad terms in international and European documents. The breach of any employee's duty seems to be enough. The Greek legislator has of course tried to "describe" these duties in the fifth Article of Law 3560/2007, requiring that they should "be determined by the law, the employment contract, internal rules, orders or instructions by supervisors or should result from the nature of the employee's position". This formulation, however, identifies only the sources of the employee's duties, and does not provide the criteria for determining their content. Thus, the concept of "duties" seems to include "any type of duties of the employee, regardless of their importance for the employer's business activities" "31, a conclusion that certainly reinforces the view that the legal interest protected by the criminal law provisions is merely a general duty of loyalty and obedience towards the employer.

However, this "duty of loyalty" lacks even the minimum necessary elements characterising a protected legal interest. Criminal law is not entitled to punish the violation of simple duties or rules. ${ }^{32}$ Moreover, if the protected value were actually loyalty to the employer, then the third party, who does not violate any duty of loyalty, should be punished in principle with a lesser penalty, as a mere participant in the actions of the employee, which is certainly not the case. Furthermore, a penalty should be foreseen only if the employee actually violated the duty of loyalty or even accepted to violate it, which is also not the case. The mere offer of undue advantages to the employee is enough.

Even if one is willing to reject the "duty of loyalty" as a protected legal interest, aiming at the underlying relationship which creates this duty, that is, the real employer - employee relationship, their view does not seem more convincing. This relationship is prejudiced by any intentional violation of the employer's orders and that is why any such violation should be made punishable and not only those due to receiving gifts or other benefits.

On the other hand, one may reasonably wonder why this employer - employee relationship might interest society to the extent that the employee should be threatened with criminal sanctions when he/she violates it. ${ }^{33}$ It is nothing more

\footnotetext{
${ }^{30}$ See Report on the draft bill "Ratification and implementation of the Criminal Law Convention on Corruption and its Additional Protocol", II.2.

${ }^{31}$ See K.Chatzikostas, Bribery in the private sector, 2010, p. 27, A. Dionysopoulou, Thoughts on active and passive bribery in the private sector [in Greek], Poinika Chronika 2009, p. 971.

${ }^{32}$ See W.Hassemer, Strafrechtlicher Rechtsgüterschutz unter der Verfassung, FS für N. Androulakis, 2003, p. 207 et seq., W. Hassemer, Die Basis des Wirtschaftsrechts, Wistra 2009, p. 172.

${ }^{33}$ See J. Vogel, Wirtschaftskorruption und Strafrecht. Ein Beitrag zu Regelungsmodellen im Wirtschaftsstrafrecht, FS für U. Weber, 2004, p. 403, 410-411, who noted that this model in its most extreme form leads to the expansion of criminal law in the area of ethics. Cf. the observations by the Bundesrechtsanwaltskammer on the draft bill by the
} 
than a private relationship, out of many that can be found in everyday life. If the employees violate the relationship of trust that links them to their employer, the latter may at any time dismiss them or file civil claims against them. ${ }^{34}$

Finally, even if one would be willing to ignore the above objections, one certainly cannot overlook the fact that the threat of criminal sanctions for the violation of all the duties of an employee that may be determined by the law, the employment contract, the internal regulations, orders or instructions from superiors or that may arise solely from the nature of the employee's position, directly violates the principle of legality, ${ }^{35}$ while the threat of criminal sanctions even for minor violations of employment duties goes against both the principle of subsidiarity in criminal law and the principle of proportionality of criminal sanctions to the seriousness of the offences.

\section{Fair competition and consumer interests}

Based on these considerations, it was suggested that a limiting interpretation of the law should be adopted, to clearly demonstrate the protected social interest. It was suggested, in particular, to add interpretively as an unwritten element in the constituent elements of the crime that the action, under the conditions performed, could lead to distortion of economic competition or to endanger the property of the company or consumers. ${ }^{36}$ One could conclude from this proposal that these are considered to be the only social values threatened by acts of bribery in the private sector, that are worthy of protection under criminal law.

Despite the fact that this effort is in line with the principle of legality in criminal law, it is difficult to adopt such an interpretation. This is not only because the link between criminal liability and the possible infringement of three different interests seems problematic, but for other reasons as well.

Starting from fair competition, it should first be noted that some of the most common forms of bribery in the private sector are undoubtedly linked to the violation of the rules of fair competition, either during product supply or in awarding projects. ${ }^{37}$ However, as already shown in the introductory examples, obtaining a competitive edge is not in any case necessary for the constituent elements of the crime. When, for instance, a bank executive approves a loan to a company facing financial problems, disregarding the bank's policy on this matter,

German Ministry of Justice, which seeks to introduce into German law a provision for bribery in the private sector similar to that in Greek law. Today, bribery in the private sector in Germany is still punishable only when fair competition is violated (BRAK, Stellungnahme der Bundesrechtsanwaltskammer zum Referentenentwurf Nr. 2-2007, p. 6).

${ }^{34}$ See similarly I. Argyroiliopoulos, Private and state corruption as a crime of unfair competition. An approach through the lens of business transactions [in Greek], 2006, p. 92 et seq.

${ }^{35}$ See K. Chatzikostas, Bribery in the private sector [in Greek], 2010, p. 72 et seq., A. Dionysopoulou, Thoughts on active and passive bribery in the private sector [in Greek], Poinika Chronika 2009, p. 972, M. Kaiafa-Gbandi, Criminal punishment of corruption in the public and private sector: the legal framework of the EU in the wider international scene and our national law [in Greek], Poinika Chronika 2010, p. 21.

${ }^{36}$ See M. Kaiafa-Gbandi, ibid., Poinika Chronika 2010, p. 21.

${ }^{37}$ See the relevant observations in I. Androulakis, Die Globalisierung der Korruptionsbekämpfung, p. 54, A. Argandoña, Private-to-private Corruption, Journal of Business Ethics 2003, p. 256. 
he/she may affect the bank's assets, but fair competition does not seem to be affected. ${ }^{38}$ Even in cases of procurement of supplies or services, granting or promising gifts or other benefits is not necessarily linked to the existence of interested competitors. This is the case when only one entrepreneur states his interest in taking over the procurement, being forced however to give money to the employee to achieve his goal, because his/her offer does not meet the criteria set by the interested employer. In this case, competition is certainly not affected. The same applies when bribery is committed in the context of monopolistic entrepreneurial activities, when again fair competition is not affected, although bribery seems to maintain its wrongfulness. 39

Furthermore, it should be noted that fair competition might in fact be affected when gifts or other advantages - mainly better prices or additional services - are offered to the owner of a private sector entity. Nevertheless, this act has not been criminalised, even if the gifts or other advantages are considered to be "unfair" in competition law. ${ }^{40}$ The wrongdoing, therefore, of the behaviour should be sought in bribing the employee to violate the duties assigned to him/her by the employer and not in the possible breach of fair competition.

This is also clear from the 2003 Framework Decision, which offered national legislators the possibility to limit the criminalisation only to conducts which involve, or could involve, a distortion of competition in relation to the purchase of goods or commercial services, by making a relevant declaration. From this rule, it can be concluded that, according to the European legislator, bribery of the employee constitutes a threat for specific social values, even when healthy competition is not affected by it. Moreover, the Greek legislator has completely ignored the possibility of limiting punishability to only include actions that affect competition, contrary to other European legislators, such as the German legislator, who have limited the criminalisation to these acts alone. ${ }^{41}$ The non-inclusion of this limitation in Greek Law shows that for the Greek legislator the link between the action and fair competition is not important.

At the same time, it should be noted that in the 2003 Framework Decision, the possibility of connecting bribery in the private sector with distortion of competition was only envisaged for five years, starting from 22 2 nd July 2005, while it was also stipulated that the Council should reconsider in due course, but no later than $22^{\text {nd }}$ July 2010, whether it would be possible to renew the member states declarations of

\footnotetext{
${ }^{38}$ See G.Heine, in:Schönke / Schröder, StGB, 27. Aufl., § 299. 23.

${ }^{39}$ See J.Vogel, Wirtschaftskorruption und Strafrecht. Ein Beitrag zu Regelungsmodellen im Wirtschaftsstrafrecht, FS für U. Weber, 2004, p. 405. See also G.Heine, Schönke / Schröder, StGB, 27. Aufl., § 299. 23, K. Tiedemann, LK - StGB, 12. Aufl., § 299. 34.

${ }^{40}$ Under the law of competition, additional benefits to customers are considered "unfair" when e. g. the value of the additional benefit is disproportionate to the value of the goods, or when the businessman exploits the public's lack of experience (See L.Kotsiris, Competition Law. Unfair and Free, [in Greek] 2000, p. 116, note 83).

${ }^{41}$ However, healthy competition is accepted as a protected legal interest by the fifth article of Law 3560/2007 by $I$. Argyroiliopoulos, Public and private corruption. A de lege ferenda approach to the phenomenon [in Greek], in: N. Kourakis (ed.) Policy Against Crime III, 2003, p. 16, I. Argyroiliopoulos, Private and state corruption as a crime of unfair competition. An approach through the lens of business transactions [in Greek], 2006, p. 98 et seq., N. Bitzilekis, Corruption as a legal and political problem [in Greek], Poinika Chronika 2009, p. 99.
} 
connecting bribery with the violation of fair competition ${ }^{42}$. As no such decision has been taken by the Council, the Commission has now ruled in its Report, published in June 2011, that the relevant member states' declarations are no longer valid and that member states that have submitted such declarations would have to amend their national legislation. For this reason, it calls upon the four states that have connected the criminalisation of bribery in the private sector with the distortion of competition in relation to the purchase of goods or commercial services, namely Germany, Austria, Italy and Poland, to amend the relevant provisions. ${ }^{43}$

Based on this report, the Commission decided in June to set up an independent mechanism for evaluating the application of its policy to tackle corruption in the public and private sector, while with its decision of $28^{\text {th }}$ September 2011, it decided to establish a group of experts for this purpose. ${ }^{44}$

Moreover, it should be noted that the 1999 Convention of the Council of Europe does not envisage a connection between bribery in the private sector and violation of competition rules. Of course, as already mentioned, the Convention offered member states the possibility of having reservations as to the criminalisation of this particular conduct. However Greece - like most member states - has kept no such reservation and is, therefore, not entitled for this reason as well to limit the punishable behaviour to acts of distortion of competition alone. ${ }^{45}$

On the other hand, the act of bribery is not necessarily linked to infringement of consumer interests. It is of course a fact that very often acts of bribery in the private sector affect such interests. This is the case, for example, when by giving undue advantages the perpetrator attempts to promote low quality products or even products hazardous for health. Moreover, in many cases, the "cost" of bribery is embedded in the cost of products, which then reach consumers with higher prices.

However, these consequences of bribery on consumers are indirect and merely probable. They are not a "constituent" element of all acts of bribery in the private sector in such a way that consumer interests would then be regarded as the protected interest infringed by those acts. On the contrary, acts of bribery in business activity may often lead to direct social benefits. ${ }^{46}$ If, for example, a business owner bribes a supermarket employee to put their own products at the most commercial places in the store, in breach of the orders of his/her employer, the interests of consumers are not necessarily affected. If these products are better than the rest in terms of quality

\footnotetext{
42 See Council Framework Decision 2003/568/JHA, on combating corruption in the private sector, Art. 2 par. 5.

${ }^{43}$ See Report of the Commission to the Council and the European Parliament under Article 9 of the Council Framework Decision 2003/568/JHA of 22. 7. 2003 on combating corruption in the private sector, 6. 6. 2011, COM (2011) 309 final.

${ }^{44}$ See EE C 286, of 30/9/2011, p. 3.

${ }^{45}$ For this reason, the proposal made recently in Greek theory for establishing a narrower concept of the crime of bribery in the private sector, adapted according to the model of the German Criminal Code, that is, a model that punishes bribery in the private sector only when it affects the rules of competition (see K. Chatzikostas, Bribery in the private sector, 2010, p. 113 et seq.), could hardly be adopted.

${ }^{46}$ See in this respect D. Bruce Johnsen, The Ethics of "Commercial Bribery": Integrative Social Contract Theory meets Transaction Cost Economics, Journal of Business Ethics 2009, p. 798.
} 
as well as the most affordable, then it is obvious that no infringement of consumers' interests can be affirmed.

\section{The property of private sector entities}

The assets of a private sector entity are also referred to as a possible legal interest affected by the act of bribery. There is no doubt that these assets are very often put at risk by such actions. When, for example, a person responsible for staff recruitment makes the selection not on the basis of their merits but on the basis of the benefits that he or she gains from them, then the possibility of selecting the less capable person may present a risk to the assets of his/her employer. The same happens when senior executives are focusing on securing funds for themselves to which they are not entitled, instead of planning long-term benefits for the businesses that employ them. And certainly the assets of the private entity are at risk when loans are granted to unreliable customers or when procurement of supplies or implementation of projects is assigned to non-reputable companies that nevertheless offer high, undue advantages to employees who are willing to act in breach of their duties. Such behaviour has had disastrous consequences for many private entities mainly in the financial sector in the recent economic crisis. ${ }^{47}$

However, again, such risks are not "constituent" elements of every act of bribery. A supplier or manufacturer can actually offer undue advantages to company executives to ensure that they will select him or her for the procurement of supplies or the implementation of projects in breach of their duties, but this act does not necessarily harm the company's assets. Instead, it is possible that both the supplies and the project offered could prove to be advantageous for the company, whose assets are not only safe, but are actually increasing. The same happens when an employee is bribed to promote - in breach of the orders of his/her employer - the product of a particular company, whose quality is the best, while its sale ensures the highest profit for the employer.

Therefore, assets of private entities, although often put in jeopardy, are not affected in any case by the act of bribery in the private sector and, for that reason, they cannot be considered as the main protected legal interest by the relevant criminal law provision.

\section{The enterprise as the protected legal interest}

It may be concluded from the above analysis that, ultimately, the crime of bribery in the private sector, as defined in both International and European texts, does not affect any existing social interest that is worthy of protection and that, therefore, legislative initiatives taken by the United Nations, the Council of Europe and the European Union will have to be reviewed towards protecting specific legal interests, such as property of companies or fair competition.

\footnotetext{
${ }^{47}$ See Transparency International, Global Corruption Report 2009, p. xxvi.
} 
However, before reaching this conclusion, we should consider whether this particular action undermines other existing social values, beyond those mentioned, the infringement of which could justify the legislative interest for broader criminalisation. In fact, the criminal law provision itself seems to offer the interpretive tools for determining this legal interest.

First of all, one can notice that both active and passive bribery are committed in the course of business activities, a term which, according to the Explanatory Report to the Criminal Law Convention on Corruption of the Council of Europe, "is to be interpreted in a broad sense: it means any kind of commercial activity, in particular trading in goods and delivering services, including services to the public (transport, telecommunication etc)". 48 To the extent that this activity is a component of both forms of bribery, it is rightly assumed that the employee should act both in the framework of the business activities of the person who bribes him/her and in the framework of the employer's business activity. ${ }^{49}$

This position leads to an additional assumption: that bribery must take place within a business transaction between the person who offers the bribe (or the entity he/she represents) and the private entity that employs the person who accepts the bribe, through which economic benefits must be pursued by both parties. This element seems to be a common feature of the most significant acts of bribery in the private sector, as described above, a fact which certainly justifies its inclusion in the definition of the crime. In this way, the duties, the infringement of which may have criminal interest, are drastically limited: Not all employees' duties are included, but only those, through which the employer's business activity towards others (persons or companies) is carried out, that is, through which entrepreneur relationships between the employer and third parties are established.

The legal interest that is violated by the act of bribery can now be deduced by the aforementioned feature. Breaching these specific duties in exchange for money to strengthen the position of another company does not constitute, evidently, a violation of a simple private relationship between employer and employee, but a deterioration of the relationship of the private entity with other companies. In the context of a business transaction, the relationship formed between the two enterprises should reflect the true will of their owners - natural or legal entities. This relationship is compromised when the expressed will of one party is undermined or impaired by a person representing him or her in favour of the counterparty, in other words, when the employee, instead of implementing the will of his/her employer, carries out the will of the businesspersons who bribed him or her and therefore appears to work only for them in the specific case. This "role change" contaminates the work environment, destabilising relations both within the business and in its dealings with other businesses.

\footnotetext{
${ }^{48}$ For the link between business activity and economic benefit see Explanatory Report to the Council of Europe Criminal Law Convention on Corruption, point 53.

${ }^{49}$ See in more detail K.Chatzikostas, Bribery in the private sector [in Greek], 2010, p. 29 et seq. See also A.Koepsel, Bestechlichkeit und Bestechung im geschäftlichen Verkehr (§ 299 StGB). Eine Fallanalyse zur Ermittlung von Anwendungsbereich und Grenzen der Norm, 2006, p. 195, K. Tiedemann, LK - StGB, 12. Aufl., § 299.21
} 
Therefore, the business itself emerges eventually as the object of protection, as an existing social entity of particular importance in modern societies, not only as a means of generating wealth for its owners, but also as a social space for securing employment. ${ }^{50}$ Of course, the business as a set of functions, equipment, employees and relationships with third parties can certainly be harmed in many ways and at all levels of operation.

But while the disruption of internal relations for any reason - with or without bribery - certainly does not constitute a matter that justifies the intervention of criminal law, for the reasons already mentioned, infringement upon its relations with other businesses has a completely different importance, as it alters its position in the field of economy. This behaviour affects the business at the core of its existence, which is the - necessary for its maintenance- realisation of transactions with third parties. Therefore, it constitutes a qualitatively different infringement, far more important to the business, without having to demonstrate any possible property damage or breach of fair competition. For this reason, its different legal treatment can be justified.

The sole connection of bribery in the private sector with acts that insult the "outward" expression of the business in developing its economic transactions - and not with every disregard of the duty of loyalty of employees towards their employers - also justifies the limitation of punishability to include actions carried out in breach of employees' duties alone. ${ }^{51}$ Because when the action is in line with the employee's duties, even if it is carried out in exchange for undue advantages, it does not impinge upon the relationship of the business with other businesses, since it does not alter its will during the transaction. This means that the employee continues to express the will of his/her employer, even if at the same time he/she satisfies somebody else's wishes.

The aforementioned connection can also justify the sole limitation of punishability of bribery for an employee's actions which will be undertaken and not for those that have already been carried out, as once the business transaction is completed, offering or taking undue advantages can no longer harm the enterprise. ${ }^{52}$

Finally, the same connection justifies equating the sentences for active and passive bribery; when the legal interest affected by the bribery is considered to be neither the private employer-employee relationship nor the duty of loyalty, but instead the enterprise itself within its business transactions with other enterprises, active and passive bribery seem to be equally harmful for it.

\footnotetext{
${ }^{50}$ See in this respect N. Livos, Responsibility of businesses and their managers for economic crimes: An example of modern design of criminal law in the European Union, [in Greek] in: Recent developments in European Financial Criminal Law, 2010, p. 98.

${ }^{51}$ See Art. 7 and 8 of the Council of Europe Criminal Law Convention on Corruption, Art. 21 of the UN Convention against Corruption and Art. 2 par. 1 of the 2003/568/JHA Framework Decision on combating corruption in the private sector. On the contrary, bribery in the public sector constitutes a crime even if the corrupt act is in line with the perpetrators duties (see Art. 15 of the UN Convention against Corruption and Art. 2 and 3 of the Council of Europe Criminal Law Convention on Corruption).

${ }^{52}$ On the contrary, according to Greek Penal Code (Art. 235), bribery in the public sector constitutes a crime not only when the public officials are bribed in order to act in the future, but also when undue advantages are offered for an already completed action.
} 


\section{The necessary legislative changes}

The identification of the social interest affected by the act of bribery determines, evidently, the changes that need to be made by legislators in the description of the crime and the threat of criminal sanctions.

\section{Clear description of the employee's duties}

The first change relates to clarifying the employee's duties, for the breach of which undue advantages are offered or taken. Neither the United Nations Convention against corruption nor the Council of Europe Criminal Law Convention on Corruption define these duties. Things seem to be different in the Framework Decision 2003/568/JHA. According to Art. 1 of this Decision, the concept of 'breach of duty' should be understood in accordance with national law, which should cover, as a minimum, any disloyal behaviour constituting a breach of a statutory duty or, as the case may be, a breach of professional regulations or instructions. From this wording, one can conclude that the European legislator asks member states to define the employee's duties, clarifying, that they should be clearly formulated in the law, regulations or instructions, so the employee could know when he/ she breaks the law. This is, of course, not the case with the relevant Greek legislation, where the employee's duties are listed, as already indicated, in an extremely broad manner, covering even duties that can be drawn from the "nature of the position". This legislation is contrary both to the principle of legality and to the indications of the EU legislature.

Further delineation also stems from the fact that, as already mentioned, bribery acts do not target all the above duties, but only those linked to the performance of a business transaction between enterprises. Even though this element can be deduced from the interpretation of the combined provisions on active and passive bribery, according to the above discussion, it should be clearly mentioned in the criminal law provisions.

\section{Redefining the circle of potential perpetrators}

In the fifth Article of the Greek Law 3560/2007, "any manager or employee in any capacity in private sector entities" is defined as a possible perpetrator of a crime of bribery in the private sector. This formulation demonstrates that the legislator wants to cover all employees of a private entity: managers, officers, workers, even apprentices. Moreover, it is not considered as crucial for the employment contract linking the persons in question with the private entity to be valid. It is considered sufficient for these persons to be included in the hierarchical structure of the private entity and to provide any work that serves its goals. Conversely, it is accepted that an authorised representative of the private entity, that is, a person operating on the private entity's behalf without being part of its hierarchical structure, such as a lawyer or financial advisor, cannot be considered as perpetrator of the crime, 
because it would go beyond the letter of the law to consider that person as an "employee in a private sector entity". 53

This restriction leads of course to an obvious contradiction, because while it is highly unlikely that the responsibility to express the will of the company in a business transaction would be handed over to an apprentice, a lawyer or financial advisor is often hired exclusively for this purpose. On the other hand, this restriction goes against what is expressly stated in the 1999 Convention of the Council of Europe, where all persons who work in any capacity for a private sector entity are indicated as possible perpetrators. According to the Explanatory Report of this Convention, this wording covers not only persons included in the hierarchical structure of the enterprise, but also lawyers, consultants, commercial representatives and in general terms, all persons who, as noted, "can engage the responsibility" of a business. $^{54}$

The problem in the wording of the text in Greek law appears to stem from the incorrect wording adopted in the translation of the Convention of the Council of Europe from the original English text into Greek. ${ }^{55}$ While the English text refers to persons employed in any capacity "for" private sector entities (any persons who direct or work for, in any capacity, private sector entities), which allows the inclusion of authorised representatives in the circle of potential offenders, the Greek translation refers to persons working "in" private sector entities. Greece has, therefore, the contractual obligation to expand the circle of potential perpetrators of punishable acts to include not only those who are integrated in the hierarchical structure of an enterprise, but also the authorised representatives to the extent that they express the will of the business thereof to third parties.

\section{Rationalisation of criminal sanctions}

Finally, an equally important change is related to the level of criminal sanctions. In Greek law, such penalties are fully equated with the penalties for bribery of state employees. Equating the two, however, is not correct.

Initially, the threat of imprisonment from five to ten years if the amount of the benefits exceeds 73,000 Euros seems to be contrary to the principle of proportionality. It is obvious that linking the penalty of bribery to the amount of the benefits is irrelevant to the protected legal interest, which is equally affected even when the offered benefits are of significantly less value. ${ }^{56}$ On the other hand, one cannot justify the fact that offering or taking undue advantages amounting to just one or two euros below the limit of 73,000 Euros is regarded to be a misdemeanour, threatened with imprisonment from one to five years, while the same action is a

\footnotetext{
${ }^{53}$ K. Chatzikostas, Bribery in the private sector [in Greek], 2010, p. 22 et seq.

${ }^{54}$ See the Explanatory Report to Criminal Law Convention on Corruption, point 54.

${ }^{55}$ In this respect K. Chatzikostas, ibid., p. 22 fn. 65.

${ }^{56}$ See a relevant critique in K. Chatzikostas, ibid., p. 79 et seq., N. Bitzilekis, Corruption as a legal and political problem [in Greek], Poinika Chronika 2009, p. 102 et seq.
} 
felony, threatened with imprisonment from five to ten years, if the advantages are worth 2 or 3 euros more. ${ }^{57}$

The legislator argues, of course, in the Explanatory Report on Law 3666/2008 that the threat of the aforementioned penalties is in line with the principle of proportionality, as it corresponds to the gravity of the penalties foreseen for the offence of bribery in the public sector. ${ }^{58}$

Regardless of the fact that the above two arguments apply equally to the crime of bribery of public officials, it should also be pointed out here that the principle of proportionality does not require equating the penalties with those for the same offences in the public sector. Acts of bribery in the private sector by nature do not have the same gravity as acts of corruption of state employees. To the extent that the state apparatus is institutionally obliged to serve all citizens, anyone can certainly discern a collective social interest in maintaining objectivity and impartiality in performing a public service. ${ }^{59}$ This, naturally, does not apply in the case of bribery of employees on behalf of a private entity, because they do not act in the common interest, but exclusively in the interest of their employers. ${ }^{60}$

This distinction between bribery in the public and the private sector is also clear from international texts referring to these crimes. It would suffice to consider that according to the United Nations Convention against Corruption member states have to criminalise bribery of state officials and employees, but it is left to their discretion to decide whether to make the bribery in the private sector a criminal offence. ${ }^{61}$ Moreover, what is particularly important is the fact that the 2003 Framework Decision itself does not require such penalties. The European legislator considers as adequate and proportionate "a penalty of a maximum of at least one to three years of imprisonment" ${ }^{\text {, }}$, while the Criminal Law Convention on Corruption of the Council of Europe requires only "effective, proportionate and dissuasive sanctions ...involving deprivation of liberty which can give rise to extradition", 63 which, according to Art. 437 of the Greek Code of Criminal Procedure, is a

\footnotetext{
${ }^{57}$ See in this respect E. Symeonidou-Kastanidou, Amendments to the Criminal Code by Law 2721/1999 [in Greek], Yperaspisi 1999, p. 1515 et seq.

${ }^{58}$ See Explanatory Report on Law 3666/2008, par. 3. This position is certainly related to a widespread view that bribery in the private sector is not essentially different from bribery in the public sector, and for that reason both crimes should be treated similarly (See I. Androulakis, Die Globalisierung der Korruptionsbekämpfung, 2007, p. 475 et seq.), or at least interpreted as if they offend the same legal interest (H. Jaques, Die Bestechungstatbestände unter besonderer Berücksichtigung des Verhältnisses der $\$ \S 331 \mathrm{ff}$. StGB zu $\S 12 \mathrm{UWG}, 1996$, p. 125 et seq.). In this context, it is argued that the common unifying element of the two types of bribery (in the public and in the private sector) is the principal-agent relationship, a relationship that is of particular importance for the functioning and productivity of modern society, which is based on the division of labour and the division of duties.

${ }^{59}$ See T. Papakyriakou, The status of increased accountability of state employees in the current Greek criminal law, Poiniki Dikaiosyni 2009, p. 1128.

${ }^{60}$ See K. Chatzikostas, Bribery in the private sector, 2010, p. 57, N. Bitzilekis, Corruption as a legal and political problem [in Greek], Poiniki Dikaiosyni 2009, p. 99 and 104, M. Kaiafa- Gbandi, Criminal punishment of corruption in the public and private sector: the legal framework of the EU in the wider international scene and our national law [in Greek], Poinika Chronika, 2010, p.21.

${ }^{61}$ See in relation to this the Legislative Guide for the Implementation of the United Nations Convention against Corruption, points 177 and 179 .

${ }^{62}$ Art. 4 par. 2 of the Framework Decision 2003/568/JHA.

${ }^{63}$ Art. 19 par. 1 of the Council of Europe Criminal Law Convention on Corruption.
} 
custodial sentence of a maximum of at least two years. Finally, of utmost importance is also the fact that in most European countries, the penalties for bribery in the private sector are significantly lower than those in Greece and, in any case, smaller than those for bribing public officials or employees. ${ }^{64}$

Based on the above, the transformation of bribery in the private sector into a simple misdemeanour punishable with up to two or three years' imprisonment, regardless of the amount of benefits acquired, seems in any case necessary, so that the principle of proportionality can be respected.

\section{Conclusion}

The above analysis demonstrates that the criminalisation of bribery in the private sector was made by the Greek legislator in a hasty manner, without examining the reasons that might justify it and without attempting to offer a clear description of the punishable conduct. Moreover, Greece not only failed to use the possibility of limiting the punishable behaviour, granted both by the Convention of the Council of Europe and the 2003 Framework Decision, but instead it has broadened the content of bribery in the private sector and ignored international standards regarding the severity of criminal sanctions.

In this way, the Greek government undoubtedly wanted to prove to the European Union, the Council of Europe and international organisations, as well as Greek citizens, its real interest and determination to address corruption wherever it occurs. This is, in fact, a common practice of many Greek governments that has been consistently followed for many decades. The Greek state has even reached the point of threatening with life imprisonment acts of bribery both in the public and in a large part of the private sector. ${ }^{65}$

${ }^{64}$ The penalties in various European countries for bribery of state employees and bribery in the private sector are indicatively shown in the table below.

\begin{tabular}{|c|c|c|}
\hline & Bribery of state employees & Bribery in the private sector \\
\hline France & confinement up to 10 years and fine of 150,000 Euros & $\begin{array}{l}\text { confinement up to } 5 \text { years and fine of } \\
75,000 \text { Euros }\end{array}$ \\
\hline Germany & $\begin{array}{l}\text { confinement from } 6 \text { months to } 5 \text { years for passive and } \\
\text { from } 3 \text { months to } 5 \text { years for active, for action carried out } \\
\text { in breach of one's duties }\end{array}$ & confinement up to 3 years or fine \\
\hline Denmark & $\begin{array}{l}\text { Active is punished with confinement up to } 3 \text { years and } \\
\text { passive with a sentence of up to } 6 \text { years. }\end{array}$ & confinement up to 18 months \\
\hline Switzerland & $\begin{array}{l}\text { confinement up to } 5 \text { years or fine for action carried } \\
\text { out in breach of one's duties }\end{array}$ & confinement up to 3 years or fine \\
\hline Cyprus & $\begin{array}{l}\text { confinement up to } 7 \text { years or fine up to } 17,000 \text { Euros } \\
\text { or both penalties }\end{array}$ & $\begin{array}{l}\text { confinement up to two years or a fine } \\
\text { of up to } 2,550 \text { Euros or both penalties }\end{array}$ \\
\hline $\begin{array}{l}\text { Luxem- } \\
\text { bourg }\end{array}$ & $\begin{array}{l}\text { confinement from } 5 \text { to } 10 \text { years and fine from } 500 \text { to } \\
187,500 \text { Euros. }\end{array}$ & $\begin{array}{l}\text { confinement from } 1 \text { month to } 5 \text { years } \\
\text { and fine from } 251 \text { up to } 30,000 \text { Euros }\end{array}$ \\
\hline Finland & $\begin{array}{l}\text { confinement from } 4 \text { months } \omega \varsigma 4 \text { years for action } \\
\text { carried out in breach of one's duties }\end{array}$ & Fine or confinement up to two years \\
\hline
\end{tabular}

This data has been collected by Evaluation Reports of the GRECO Committee.

${ }^{65}$ See Article 1 Law 1608/1950 in combination with Article 263 ${ }^{\mathrm{A}}$ of the Criminal Code. 
The deterrent effect of such practice is, without doubt, well known. In the latest report of Transparency International for 2011, Greece holds the 80th place in terms of tackling corruption, together with Colombia and El Salvador. ${ }^{66}$ The real interest in tackling corruption in both the public and private sector cannot be proven, in whole or in part by the threatening of severe criminal sanctions. It is primarily a matter of political will to formulate new standards of behaviour, to highlight the impact of the act in question, to organise mechanisms for detecting the phenomenon and ultimately to implement the criminal law. If the law is applied, then even minor penalties act effectively.

\footnotetext{
${ }^{66}$ See Corruption Perceptions Index 2011, the perceived levels of public-sector corruption in 183 countries/ territories around the world (www.transparency.org/publications).
} 